\title{
The Pineal Gland is Critical for Circadian Period I Expression in the Striatum and for Circadian Cocaine Sensitization in Mice
}

\author{
Tolga Uz*,', Mustafa Akhisaroglu', Rehan Ahmed' and Hari Manev' \\ 'The Psychiatric Institute, Department of Psychiatry, University of Illinois at Chicago, Chicago, IL, USA
}

\begin{abstract}
Sensitization to psychostimulants can be influenced by circadian rhythms. The pineal gland, the main source of circadian melatonin synthesis, may influence behavioral sensitization to cocaine; mice with normal melatonin rhythms do not get sensitized at night. Clock genes such as Periodl (Perl) show rhythmic region- and strain-dependent expression in the mouse brain, and mice mutant for the Perl gene lack cocaine sensitization. Here, for the first time we show circadian changes of PERI protein levels in the mouse striatum, a brain region crucial for the development of locomotor sensitization to cocaine. In male $\mathrm{C} 3 \mathrm{H} / \mathrm{HeJ}$ mice, we found peak striatal PERI protein levels during the day; this was preceded by a Perl mRNA peak $16 \mathrm{~h}$ earlier. Pinealectomized mice did not show this circadian pattern. We analyzed circadian cocaine sensitization at times when striatal PERI protein levels in control mice (naive and sham-pinealectomized) were high and low, respectively. Only mice with circadian changes in striatal Perl expression showed the night-time absence of cocaine sensitization, whereas pinealectomized mice were without circadian changes in striatal Perl and were sensitized to cocaine regardless of diurnal rhythm. Our results indicate that both the striatal circadian Perl expression and diurnal locomotor cocaine sensitization are strongly influenced by pineal products. Since we found evidence for the expression of melatonin receptor mRNA in the striatum, we suggest that further studies on pineal-driven mechanisms will help us better understand the mechanisms of drug abuse and identify novel targets for the prevention and/or treatment of addictions.

Neuropsychopharmacology (2003) 28, 21 1 7-2123, advance online publication, 09 July 2003; doi: I 0. I 038/s.npp. 1300254
\end{abstract}

Keywords: arylalkylamine $\mathrm{N}$-acetyltransferase; $\mathrm{N}$-acetylserotonin; melatonin; addiction; $\mathrm{C} 3 \mathrm{H} / \mathrm{Hej}$; mouse; clock genes

\section{INTRODUCTION}

Psychostimulants, such as cocaine and amphetamine, show circadian rhythmicity in their behavioral effects in rodents (Gaytan et al, 1999, 2000; Uz et al, 2002a), moreover chronic cocaine users show seasonal rhythmicity in their cravings and in drug abuse (Satel and Gawin, 1989; Sandyk and Kanofsky, 1992).

Behavioral sensitization is a process in which repeated exposure to a drug results in increased behavioral responses and that is common across the species; that is, from fruit flies (Drosophila) to humans (Robinson and Berridge, 1993; Prinssen et al, 1996; Andretic et al, 1999; Sax and Strakowski, 2001). Recent work using Drosophila has identified a family of circadian 'clock genes' as an important contributor to the development of cocaine sensitization (for a review, see Wolf, 1999; Hirsh, 2001). Thus, flies mutant for

\footnotetext{
*Correspondence: Dr T Uz, Psychiatric Institute, University of Illinois at Chicago, I60I West Taylor Street, M/C 912, Chicago, IL 606I2, USA, Tel: + I 312413 4580, Fax: + I 3124134569 ,

E-mail: uz@psych.uic.edu

Received 21 February 2003; revised 23 April 2003; accepted 23 May 2003

Online publication: 30 May 2003 at http://www.acnp.org/citations/ Npp053003076/default.pdf
}

these genes, including Period (Per), do not sensitize to cocaine (Andretic et al, 1999).

It is believed that the mammalian clock system is hierarchical, with a master clock located within the suprachiasmatic nucleus (SCN). In the mouse circadian clock, Clock and Bmall are two transcription factors critical for the regulation of expression of three period genes (Per1, Per2, and Per3) and two cryptochrome genes (Cryl and Cry2) (Etchegaray et al, 2003; Morse and Sassone-Corsi, 2002). In a follow-up on Drosophila work (Andretic et al, 1999), it was found that mice deficient (ie 'knockout') for Per1, but not Per2, do not develop behavioral sensitization to cocaine (Abarca et al, 2002).

Recently, we provided first evidence that the development of behavioral sensitization to cocaine in mice depends on circadian rhythms (Uz et al, 2002a). Thus, mice with regular pineal melatonin rhythms sensitize to cocaine during the day, but do not show cocaine sensitization at night when melatonin levels are the highest.

The pineal gland is a key organ that influences mammalian circadian and seasonal rhythms. In this gland, melatonin is synthesized from serotonin via arylalkylamine $\mathrm{N}$-acetyltransferase (AANAT), which produces rate-limiting intermediate $\mathrm{N}$-acetylserotonin (NAS). In rodents, AANAT mRNA content (Roseboom et al, 1996; Uz et al, 2002b) and 
NAS and melatonin levels (Goto et al, 1989; von Gall et al, 2000) are marked by a circadian rhythm with high levels at night and low or even undetectable levels during the day. Recent findings indicate that the pineal gland also contributes to circadian cocaine sensitization; mice mutant for AANAT, whose pineal glands are incapable of synthesizing NAS and melatonin, do not show diurnal cocaine sensitization (Uz et al, 2002a).

It is possible that pineal products might influence not only circadian behavioral sensitization but also Per rhythm, particularly in the striatum, a brain region directly involved in behavioral cocaine sensitization. Although the rhythmic expression of Per1 in the SCN is an autonomous process independent of the pineal gland, there are regions outside the SCN where the rhythm of Perl expression depends on this gland. For example, using pinealectomy (removal of the pineal gland) in hamsters, Messager et al (2001) demonstrated that pineal products are essential for rhythmic Per1 expression in the hypophyseal pars tuberalis (PT), but not in the SCN. Similar results were obtained in experiments with mice (von Gall et al, 2002).

Here, we hypothesize that the pineal gland may serve as an independent and critical oscillator for the striatal Per1 rhythm via its products, NAS and/or melatonin, and that this pineal gland-driven Per1 rhythm is essential for the development of diurnal behavioral sensitization to cocaine. Thus, using diurnal rhythms as a model in normal and pinealectomized mice, we characterized the striatal expression of Per1 mRNA, PER1 protein, and the development of behavioral cocaine sensitization.

\section{MATERIALS AND METHODS}

\section{Animals and Drug Treatment}

Male $\mathrm{C} 3 \mathrm{H} / \mathrm{HeJ}$ mice, 8 weeks old and weighing 25-30 g, were purchased from Jackson Laboratories (Bar Harbor, ME, USA). Pinealectomized and sham-operated $\mathrm{C} 3 \mathrm{H}$ mice of the same age and weight were purchased from Taconic (Germantown, NY, USA). Animals (36 naive, 60 shampinealectomized, and 60 pinealectomized) were housed in groups of three and had free access to laboratory chow and water except during behavioral experiments. They were kept in a temperature-controlled room under conditions of $14 \mathrm{~h}$ light: $10 \mathrm{~h}$ dark cycle (lights on at $5 \mathrm{am}$; Zeitgeber time 00 [ZT00]). Cocaine hydrochloride (Sigma Chemical Co., St Louis, MO, USA) was dissolved in sterile physiological saline $(0.9 \% \mathrm{NaCl})$ and administered intraperitoneally $(20 \mathrm{mg} / \mathrm{kg}$; i.p.) in an injection volume of $0.05 \mathrm{ml} / 25 \mathrm{~g}$ body weight. This dose of cocaine was selected based on our previous dose-response studies ( $\mathrm{Uz}$ et al, 2002a). The experimental protocol was approved by the Institutional Animal Care Committee.

\section{Sample Preparation}

Brain samples were taken every $4 \mathrm{~h}$ over a $24-\mathrm{h}$ period, starting at ZT01 (during the dark periods, samples were collected under dim red light) or at ZT05 and ZT20 only. Since the caudate-putamen $(\mathrm{CPu})$ and nucleus accumbens (NAc) of the striatum play an important role in the initiation and maintenance of behavioral sensitization
(Robinson and Berridge, 1993), we analyzed these areas in samples obtained from individual animals, and quantified their Per 1 mRNA and protein levels. For this purpose, the $\mathrm{CPu}$ and NAc were excised from 1-mm-thick coronal brain slices (Bregma 1.54-0.74 mm; Paxinos and Franklin, 2001) using a 12-gauge syringe needle as described elsewhere (Terwilliger et al, 1991). In these experiments, due to the small sample sizes, different sets of animals were used to quantify mRNA and protein amounts, respectively. Since we observed similar mRNA and protein expression patterns in these specific areas, for all other experiments we used the entire striatum. For this purpose, the striatum was isolated by gross dissection and processed individually; each sample was split in half for mRNA and protein assay, respectively. Punched and gross-dissected tissues were frozen immediately on dry ice and stored at $-80^{\circ} \mathrm{C}$ until assay.

\section{RNA Extraction and Quantitation}

Due to the small size of mouse brain samples, the total RNA was extracted applying the chemical isolation method with TRIzol $^{\circledR}$ reagent (Invitrogen, Carlsbad, CA, USA) following the manufacturer's instructions. To eliminate possible DNA contamination, RNA samples were treated with a DNase reagent, DNA-free ${ }^{\mathrm{TM}}$ (Ambion, Inc., Austin, TX, USA). The yield of total RNA was determined by measuring the absorbance of an aliquot of the precipitated stock at a wavelength of $260 / 280 \mathrm{~nm}$. Furthermore, to test possible DNA contamination, each sample was run by RT-PCR without adding the reverse transcriptase enzyme (see below).

Amplification primers were ordered from Integrated DNA Technologies, Inc. (Coralville, IA, USA). The primer pairs were designed to allow amplification of 149-536 bp for the mouse Perl gene (mPer1; Sun et al, 1997) (F:5'-ATGGCTCAAGTGGCAATGAGTCCA-3'; R:5'-CTGGTTAGCCTGAACCTGCTTGAC-3'), of 176-473 bp for the cyclophilin (cyc; Hasel and Sutcliffe, 1990) (F:5'-ATTTGGCTATAAGGGTTCCTC-3'; R:5'-ACGCTCCATGGCTTCCACAAT- $3^{\prime}$ ), of $367-874 \mathrm{bp}$ for the melatonin 1 receptor (MT1; Roca et al, 1996) (5'-GGATCGCTATGAACCGTTACTGCT; 3 '-AGCTGTTGAAGTACGCCAGGTAGT), and of $10-343 \mathrm{bp}$ for the melatonin 2 receptor (MT2; Weaver et al, 1996) (5'-TCTGTCATAGTACCACCTACCACC; $3^{\prime}$ TGGTTAGGAAACTGCGCAAATCAC). Each primer contained comparable $\mathrm{G}+\mathrm{C}$ content to minimize variability in hybridization efficiency at the annealing temperature.

To allow coamplification of mPerl with the more abundant $c y c$ mRNA, pilot studies were conducted to determine optimal relative primer concentration and cycle number, whereby the PCR would still be within the exponential phase of amplification for all transcripts. The assay is described elsewhere (Uz and Manev, 1998). Briefly, striatal total RNA from each sample $(0.5 \mu \mathrm{g}$ of starting amount) was denaturated at $80^{\circ} \mathrm{C}$ for $6 \mathrm{~min}$ and then reverse transcribed with cloned Moloney murine leukemia virus (M-MLV) reverse transcriptase (200 U; Invitrogen, Carlsbad, CA, USA) in reverse transcription (RT) buffer containing $50 \mathrm{mM}$ Tris- $\mathrm{HCl}, \mathrm{pH} 8.3,75 \mathrm{mM} \mathrm{KCl}, 3 \mathrm{mM}$ $\mathrm{MgCl}_{2}$, and $1 \mathrm{mM}$ deoxynucleotide triphosphate (dNTPs; Invitrogen, Carlsbad, CA, USA) using random hexamers ( $5 \mathrm{mM}$; Pharmacia Biotech, Piscataway, NJ, USA) and 
ribonuclease inhibitors (HPRI, $28 \mathrm{U}$; Amersham, Piscataway, NJ, USA) in a volume of $20 \mu \mathrm{l}$. The RT mixture was incubated at $37^{\circ} \mathrm{C}$ for $60 \mathrm{~min}$ to promote cDNA synthesis. The reaction was terminated by heating the samples at $98^{\circ} \mathrm{C}$ for $5 \mathrm{~min}$ and then rapidly chilling on ice. The cDNA aliquots containing reverse-transcribed material and specific primer pairs (mPer $1 /$ cyc, $0.5 \mu \mathrm{M} / 0.1 \mu \mathrm{M})$ were amplified with Hot Tub DNA polymerase (Amersham, Piscataway, NJ, USA) in a thermal cycler (9600, PerkinElmer, Wellesley, MA, USA). The PCR mixture was amplified for 24 cycles with denaturation $\left(94^{\circ} \mathrm{C}, 15 \mathrm{~s}\right)$, annealing $\left(60^{\circ} \mathrm{C}, 30 \mathrm{~s}\right)$, and elongation $\left(72^{\circ} \mathrm{C}, 30 \mathrm{~s}\right)$ amplification steps. The reaction was terminated with a 5-min final elongation step. Trace amounts of $\left[{ }^{32} \mathrm{P}\right] \mathrm{dCTP}(0.5 \mu \mathrm{Ci} /$ sample; Amersham, Piscataway, NJ, USA) were included during the PCR step for subsequent quantification. To quantify the amount of the product corresponding to the amplified mRNA, the ethidium bromide-stained bands were excised from the electrophoresis gels and counted ( $\mathrm{Uz}$ and Manev, 1998).

The MT1 and MT2 receptor-specific primers were used only to demonstrate the expression of their respective mRNAs in the CPu and NAc areas of the striatum. RT-PCR conditions for these primers were the same as for mPerl, except the number of cycles, 30 .

\section{Quantitative mPER1 Western Immunoblotting}

To quantitate the levels of mouse PER1 protein (mPER1) in the striatum, striatal tissue was homogenized in a buffer containing $20 \mathrm{mM}$ Tris- $\mathrm{HCl}, 2 \mathrm{mM}$ ethylene glycol-bis $(\beta$ aminoethyl ether)- $N, N, N^{\prime}, N^{\prime}$-tetraacetic acid, $5 \mathrm{mM}$ ethylenediamine tetraacetic acid, $1.5 \mathrm{mM}$ pepstatin, $2 \mathrm{mM}$ leupeptin, $\quad 0.5 \mathrm{mM}$ phenylmethylsulfonylfluoride, $0.2 \mathrm{U} / \mathrm{ml}$ aprotinin, and $2 \mathrm{mM}$ dithiothreitol. After reading the protein content of the tissue homogenate, $40-80 \mu \mathrm{g}$ samples and gel loading solution $(50 \mathrm{mM}$ Tris- $\mathrm{HCl}$ [pH 6.8], $4 \% \beta$ mercaptoethanol, $1 \%$ sodium dodecylsulfate (SDS), $40 \%$ glycerol, and a trace amount of bromphenol blue) were mixed and boiled for $3 \mathrm{~min}$. They were loaded onto a $7.5 \%$ (w/v) acrylamide gel using the Mini Protean II gel apparatus (Bio-Rad, Hercules, CA, USA). The gels were run using $25 \mathrm{mM}$ Tris-base, $192 \mathrm{mM}$ glycine, and $0.1 \%$ (w/v) SDS at $150 \mathrm{~V}$. The proteins were subsequently transferred electrophoretically to an ECL nitrocellulose membrane (Amersham, Piscataway, NJ, USA) using the Mini TransBlot transfer unit (Bio-Rad, Hercules, CA, USA) at $150 \mathrm{~mA}$ constant current overnight. The transfer buffer contained $25 \mathrm{mM}$ Tris-base, $192 \mathrm{mM}$ glycine, and $20 \%$ methanol. Membranes were washed with TBST buffer $(10 \mathrm{mM}$ Trisbase, $0.15 \mathrm{M} \mathrm{NaCl}$, and $0.05 \%$ Tween-20) for $10 \mathrm{~min}$. The blots were incubated with anti-mouse PER1 antibody $(4 \mu \mathrm{g} /$ ml; Alpha Diagnostic International, Inc., San Antonio, TX, USA) in $5 \%(\mathrm{w} / \mathrm{v})$ powdered nonfat milk in TBST, $2 \mathrm{ml} \mathrm{NP}-$ 40 , and $0.02 \%(\mathrm{w} / \mathrm{v})$ SDS ( $\mathrm{pH} 8.0$ ) overnight. The blots were then washed with TBST and incubated with the horseradishperoxidase-linked secondary antibody (anti-rabbit IgG; 1:1000; Amersham, Piscataway, NJ, USA) for $4 \mathrm{~h}$ at room temperature and processed with an ECL kit; blots were then washed with TBST and exposed to Hyperfilm ECL (Amersham, Piscataway, NJ, USA). To normalize the signal for mPER1 protein, the presence of noninducible $\beta$-actin protein was measured on the same blot using a mouse monoclonal antibody against the $\beta$-actin ( $1: 5000$; Sigma, St Louis, MO, USA). The mPER1 protein produced the expected size band at $140 \mathrm{kD}$ as described by others (von Gall et al, 2001), while the $\beta$-actin band appeared at $42 \mathrm{kD}$ (Figure 1a). The optical densities of the mPER1 bands were corrected by the optical density of the corresponding $\beta$ actin bands on the film using the Loats Image Analysis System (Loats Associates, Inc., Westminster, MD, USA).

\section{Locomotor Activity Measurements, Behavioral Sensitization}

Mice who had not been previously exposed to the testing monitors were weighed and placed individually in mouse activity cages for a 30-min adaptation period. After this period, locomotor activity was measured for $30 \mathrm{~min}$ using the Cage Rack Photobeam Activity Measurement System (San Diego Instruments, Inc., San Diego, CA, USA) equipped with computer-monitored photobeam frames. Immediately after the second 30-min interval, animals were injected with cocaine and returned to their activity cages; the recording procedure continued for an additional 30-min period. Times of injections were daytime: ZT05-10 am, and night-time: ZT20-1 am. The movement of each animal was recorded as the number of beam interruptions and reported as locomotor activity (ambulation). The experimental room was illuminated by normal fluorescent light (about 150 lux at the bench level) operated with a light timer; the night-time drug administrations were carried out under dim red light ( 0.1 lux at the bench level). After each experimental session, animals were returned to their home cages. To measure the development of locomotor sensitization, the same procedure was repeated for 3 consecutive days and nights (Uz et al, 2002a).

\section{Statistical Analysis}

Optical density values and radioactivity counts (both calculated as ratio, mean \pm SEM) were evaluated by analysis of variance (ANOVA) followed by $t$-test. Locomotor activity scores (mean \pm SEM) were analyzed by two-way ANOVA with the factors of the strains and the time of the day separately, followed by the Dunnett's multiple comparison test. Significance was accepted as $p<0.05$.

\section{RESULTS}

\section{Circadian Striatal mPer1 mRNA and Protein Expression}

To investigate the rhythm of mPerl gene expression in the striatum, we used NAS/melatonin-proficient naive $\mathrm{C} 3 \mathrm{H}$ inbred mice and measured the 24-h-cycle content of mPer 1 mRNA applying RT-PCR. We also measured mPER1 protein levels employing Western immunoblotting with a specific mPER1 antibody. We found that diurnal mPer1 mRNA expression in the striatum peaked at ZT13. Following this mRNA peak, within $8 \mathrm{~h}$ mPER1 protein levels started to elevate and peaked at ZT05 (daytime; $16 \mathrm{~h}$ following the mRNA peak). The PER1 levels in the striatum were at their lowest between ZT17 and ZT21 (nighttime) (Figure $1 \mathrm{a}$ and b). 


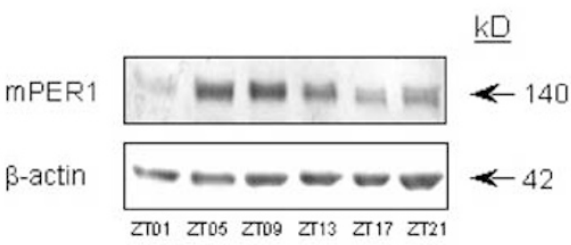

b

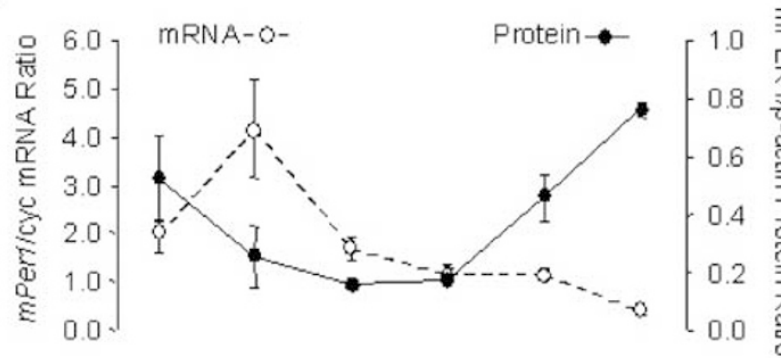

c

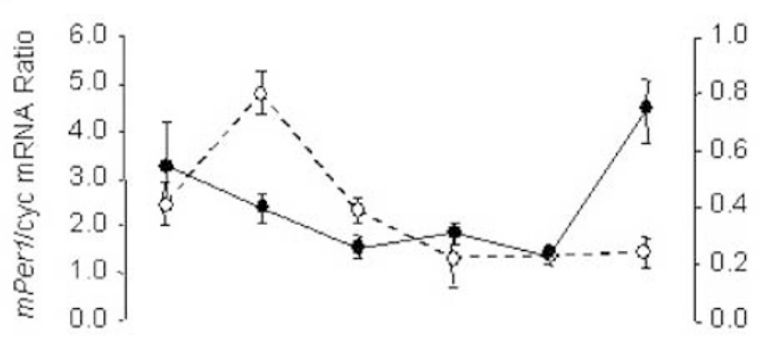

d

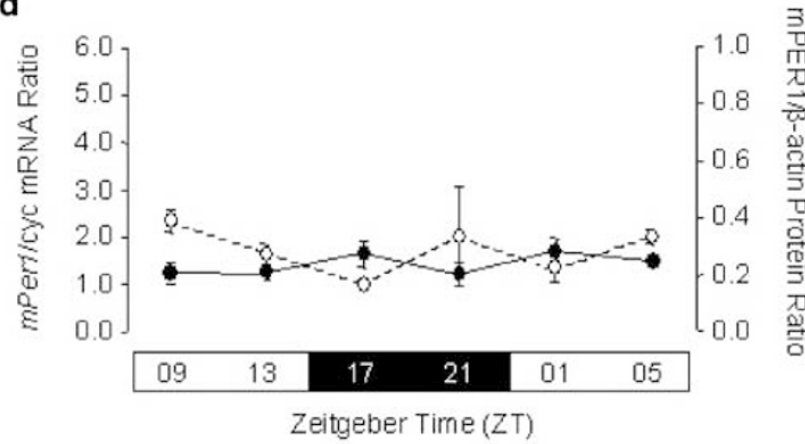

Figure I Removal of the pineal gland abolishes the mPer/ mRNA and mPERI protein rhythm in the striatum of $\mathrm{C} 3 \mathrm{H}$ mice. Mice with an intact pineal gland, either naive (a, b) or sham-operated (c), demonstrate similar rhythmic mPerl gene expression in the striatum, whereas pinealectomized mice show no rhythm over a $24 \mathrm{~h}$ period (d). Panel (a) shows an example of the mPERI Western immunoblot from a striatal sample taken from naive $\mathrm{C} 3 \mathrm{H}$ mice. The mPERI-specific antibody detected an expected size (around $140 \mathrm{kD}$ ) band. For the quantitative assay, the period protein and mRNA signals were normalized by the corresponding $\beta$-actin or cyclophilin (cyc) signals, respectively. The results of the quantitative assay (panels b-d) are the mean \pm SEM, obtained from three animals from each time point ( $n=18$ for each group, that is, naive, sham-operated, and pinealectomized). The results are shown as ratios of mPerl/cyclophilin (cyc) for mRNA (broken lines with open circles) and mPERI/ $\beta$-actin for protein (solid lines with closed circles). Note that in both control groups, the peak levels of mRNA (ZTI3) precede the peak levels of protein (ZT05) and that no rhythm is observed in pinealectomized mice. The zeitgeber time 00 (ZTO0) is defined as lights on. a
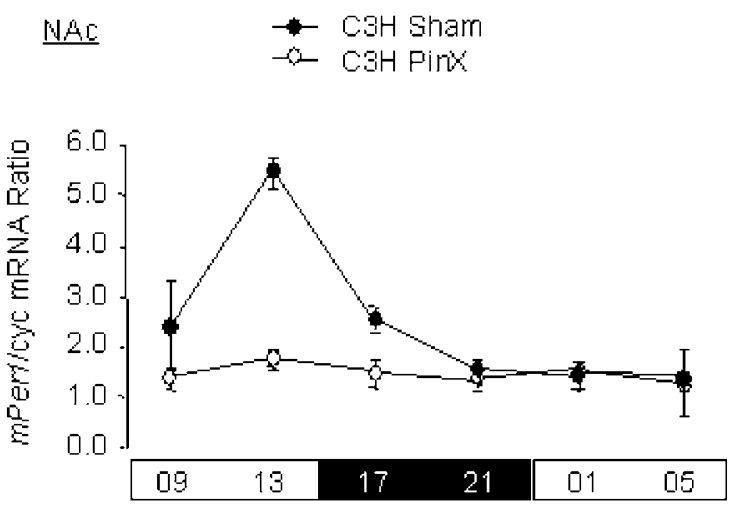

Zeitgeber Tirne ( $Z \mathrm{~T})$

b

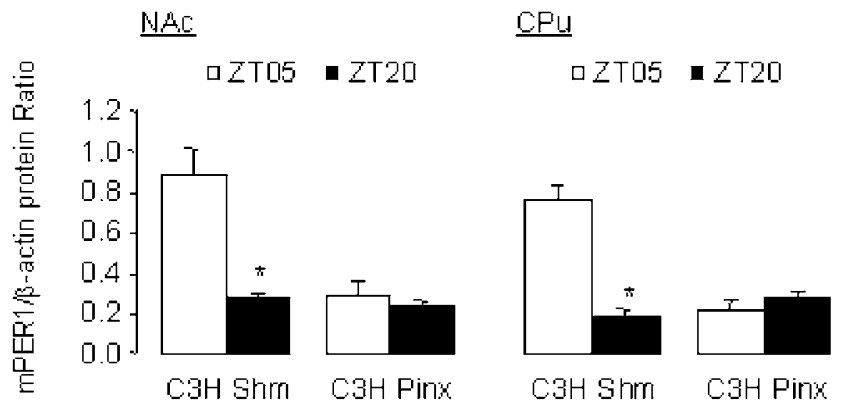

Figure 2 Pinealectomy affects the rhythm of the mPerl gene in the NAc and the CPu of the striatum. The mPerl mRNA levels were assayed in the NAc of control (closed circles) and pinealectomized (open circles) mice (I8 per group; three per each time point) over a $24 \mathrm{~h}$ period (a). Note the absence of a ZT I 3 peak in the pinealectomized mice. The mPERI protein content was assayed in both the NAc and CPu at the time points selected for cocaine injections (ie daytime, ZT05 vs night-time, ZT20; three mice per group) (b). The nighttime values are significantly lower compared with the corresponding daytime values $(* p<0.05 ; t$-test). Note that pinealectomized and control mice show similar (ie low) daytime and night-time mPERI values (b).

Pinealectomy had a major effect on the circadian expression of striatal mPer1. Hence, the rhythm of both mPer 1 mRNA and mPER1 protein was intact in shampinealectomized mice (Figure 1c) and absent in pinealectomized $\mathrm{C} 3 \mathrm{H}$ mice (Figure 1d). Moreover, in pinealectomized mice the striatal content of mPer1 mRNA and mPER 1 protein was relatively low; that is, in the range of the low diurnal levels observed in naive or sham-pinealectomized mice.

Similar results were obtained in two subregions of the striatum, the NAc and $\mathrm{CPu}$. Thus, the rhythm of mPerl mRNA in the NAc of control mice was similar to the rhythm in the entire striatum, whereas in the NAc of pinealectomized mice this rhythm was absent (Figure 2a). In both the NAc and $\mathrm{CPu}, \mathrm{mPER} 1$ protein levels were decreased by pinealectomy, measured at ZT05. At ZT20, mPER1 protein levels were low in both control and pinealectomized mice (Figure $2 b$ ).

\section{Diurnal Behavioral Cocaine Sensitization}

We previously reported that NAS/melatonin-proficient mice (ie $\mathrm{C} 3 \mathrm{H}$ ) show circadian sensitization to cocaine; they do 
not develop sensitization when the drug is given repeatedly at night, but sensitization is developed after repeated daytime drug administrations. On the other hand, AANAT-mutant C57BL (ie NAS/melatonin-deficient) mice lack this diurnal pattern and sensitize to cocaine both during the day and night (Uz et al, 2002a). Here, we used the naive $\mathrm{C} 3 \mathrm{H}$ mice to replicate our original findings (a positive control), and we added additional groups; pinealectomized $\mathrm{C} 3 \mathrm{H}$ mice and their sham-operated controls. We confirmed the pineal NAS status of control mice at two time points selected for cocaine administration, that is, the daytime-ZT05, and the nighttime-ZT20. Hence, the pineal NAS was detectable at ZT20 and absent at ZT05 (data not shown).

We selected ZT05 and ZT20 as the times for cocaine administration based on our findings that in normal $\mathrm{C} 3 \mathrm{H}$ mice, these are the time points when striatal mPER 1 protein contents are high and low, respectively. Figure 3 shows that all the above-noted experimental groups developed cocaine sensitization after the third daytime injection, whereas the nighttime injections failed to produce sensitization both in naive and sham-pinealectomized control mice. On the other hand, nighttime cocaine injections did produce sensitization in the pinealectomized mice (Figure 3).

\section{Melatonin Receptor mRNA in the Striatum}

We investigated whether the mRNAs for two melatonin receptor subtypes, MT1 and MT2, are expressed in the $\mathrm{CPu}$ and NAc regions of the striatum. Figure 4 shows that both mRNAs are present in the mouse striatum.

\section{DISCUSSION}

Behavioral sensitization, also termed reverse tolerance, is characterized by progressive and long-lasting behavioral changes that develop after repeated administration of stimulant drugs (Robinson and Berridge, 1993) and may involve lasting alterations in gene expression. Cocaineinduced behavioral sensitization has been commonly used as an experimental model across the species (Prinssen et al, 1996; Andretic et al, 1999; Sircar, 2000), since it replicates repetitive drug taking in humans and also promotes the drug cravings and further addictive behaviors seen in drug dependence (Robinson and Berridge, 1993; Sax and Strakowski, 2001).

The main finding of our work is that the pineal gland has a prominent permissive role both for the circadian expression of striatal mPer 1 and for the development of diurnal behavioral sensitization to cocaine. Thus, we observed a strong positive correlation between the rhythmic mPER1 protein level changes in the striatum and the development of diurnal locomotor cocaine sensitization. Consequently, when striatal mPER1 rhythm was abolished, for example, by pinealectomy, diurnal cocaine sensitization was abolished as well and the mice became cocainesensitized despite their diurnal cycle.

A number of studies have established that alterations in the functioning of basal ganglia are linked to the appearance of sensitization phenotypes and that the striatum is a region crucial for the development and maintenance of behavioral a

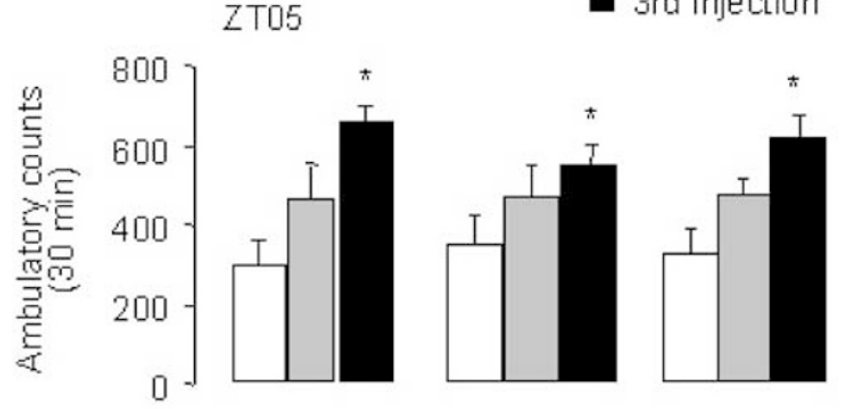

b

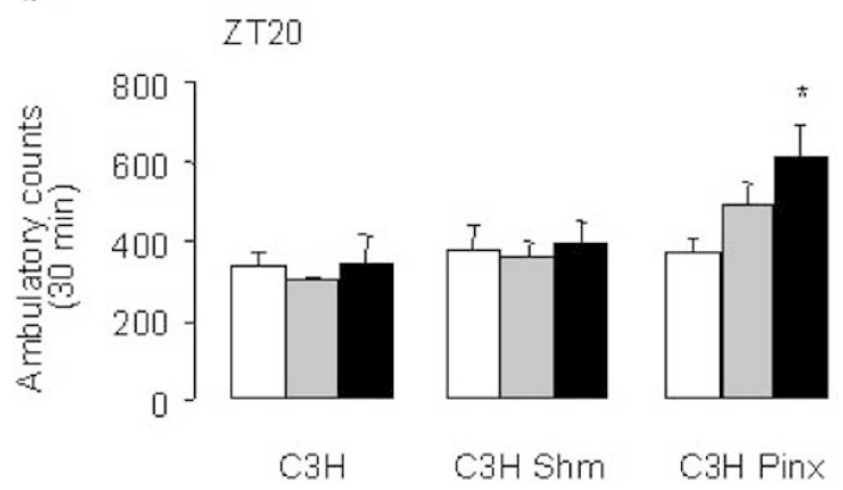

Figure 3 The critical role of the pineal gland in the development of a diurnal pattern of cocaine sensitization. Cocaine sensitization was studied in naive $(\mathrm{C} 3 \mathrm{H})$, sham-pinealectomized $(\mathrm{C} 3 \mathrm{H} \mathrm{Shm})$ mice, and pinealectomized (C3H Pinx) mice. Cocaine was administered for 3 consecutive days either during the day (ZT05) (panel a) or at night (ZT20) (panel b). Results (mean $\pm \mathrm{SEM} ; n=9 /$ group/time point) are expressed as locomotor activity; that is, the number of beam breaks during a 30-min test session. Note the development of sensitization to cocaine (increased locomotor activity after the third injection) in all groups injected at ZT05, the absence of sensitization in control mice at ZT20, and the reappearance of night-time sensitization in pinealectomized mice. ${ }^{*} p<0.05$ in comparison with the corresponding first injection values (Dunnett's test).

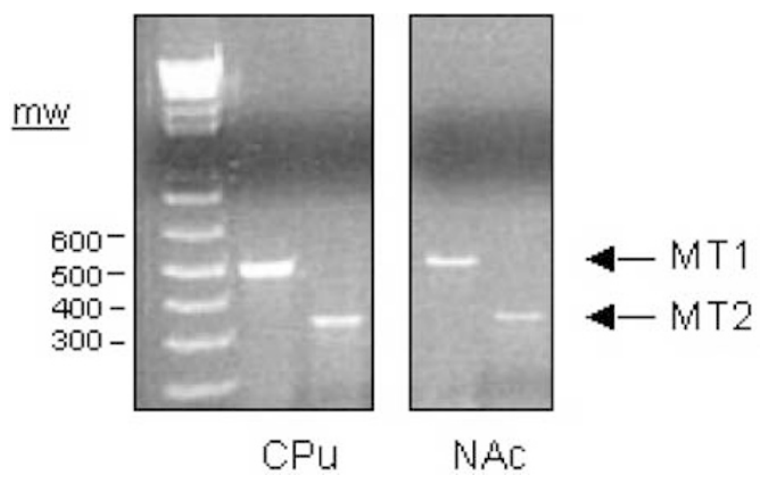

Figure 4 Melatonin receptor MTI and MT2 mRNAs are expressed in the Cpu (left panel) and the NAc (right panel) of the mouse striatum. The presence of MTI and MT2 mRNAs was detected using the corresponding primer pairs and the RT-PCR assay (see Materials and methods for details).

sensitization to cocaine (Robinson and Berridge, 1993). Work with methods that disrupt gene expression has demonstrated that several genes may be required for the 
development of cocaine sensitization in mice (Laakso et al, 2002). Abarca et al (2002) used knockout mice that do not express $m$ Per 1 or $m P e r 2$ and found that the mPer 1 , but not the $m P e r 2$ gene, is required for the development of cocaineinduced locomotor sensitization. The importance of the Per pathway is suggested by the finding that for cocaine sensitization to occur in different species, Per expression is obligatory. Thus, fruit flies mutant for clock genes, including Per, failed to develop behavioral cocaine sensitization (Andretic et al, 1999).

Since one of the prominent features of clock genes, which encode a set of transcriptional modulators, is their cyclic expression, we postulate that in addition to its general permissive role (demonstrated by the absence of cocaine sensitization in Per-null mutants), the rhythm of mPER1 protein in the striatum might be involved in diurnal cocaine sensitization in mice. Even though all three $m$ Per isoforms cycle at both the mRNA and the protein levels in the SCN, mPer1 also shows region-specific and SCN-independent expression rhythm (von Gall et al, 2001; Sun et al, 1997; Iijima et al, 2002). Since SCN is thought to coordinate and regulate behavioral clocks in mammals, only a few studies have explored the SCN-independent rhythms of clock genes in the brain. Similar to our findings, Iijima et al (2002) observed SCN-independent mPer mRNA expression in the mouse striatum.

Our results demonstrate for the first time that the levels of both mPer 1 mRNA and mPER1 protein cycle in the mouse striatum. It is the PER protein and not the mRNA that may regulate gene transcription; for example, at the promoter level by interfering with the other clock protein/transcription factors (Stanewsky, 2003). Thus, the information on the rhythm of PER protein levels as opposed to mRNA levels in a brain region, such as the striatum, appears to be relevant for understanding the putative link between Per expression and cocaine sensitization. In naive and sham-pinealectomized mice, sensitization occurred when cocaine was injected at ZT05 (high striatal mPER1) and it did not develop if cocaine was injected at ZT20 (low striatal mPER1). Interestingly, pinealectomized mice, who also lack rhythmic striatal mPer 1 expression, developed sensitization to repeated cocaine injections at all time points, even at ZT20, when mPER1 protein levels in the striatum are low. These results indicate that the rhythm of mPER 1 protein is as important as the absence (Abarca et al, 2002) of this protein for the suppression of cocaine sensitization. Alternatively, since our study addressed the total, but not the cell-specific mPerl expression in the striatum, it is possible that mPer 1 expression in certain cell populations is more affected and/or relevant for the development of cocaine sensitization. This possibility should be explored in future studies.

A critical role of the pineal gland and its products for the SCN-independent expression of Per 1 has been inferred from the effects of pinealectomy on the rhythm of Per1 expression in the pituitary cells of hamsters and mice (Messager et al, 2001; von Gall et al, 2002). In these experiments, not only pinealectomy but also the knockout of the melatonin MT1 receptors abolished the diurnal rhythm of the PT mPER1 protein (von Gall et al, 2002). Since MT1 receptors respond to both melatonin and NAS (Dubocovich et al, 1999), it is likely that the pineal gland- dependent rhythms of striatal and pituitary mPer1 expression involve these receptors, and also pineal products such as NAS and melatonin. In support of this possibility, we found evidence for the striatal expression of MT1 and MT2 receptor mRNA in the striatum. These receptors are members of a superfamily of seven-transmembrane domain G-coupled receptors (Reppert et al, 1995; Roca et al, 1996) for which specific ligands are being developed (Dubocovich et al, 1999), and pharmacological experiments (Sircar, 2000) could further elucidate a putative role for the striatal melatonin receptors in cocaine sensitization.

In our previous work (Uz et al, 2002a), we observed a dramatic difference in the occurrence of diurnal cocaine sensitization between $\mathrm{C} 3 \mathrm{H}$ mice and $\mathrm{C} 57 \mathrm{BL}$ mice-similar to pinealectomized mice, the latter strain lacked the diurnal pattern of sensitization and sensitized to cocaine both during the day and at night. We proposed that the absence of nocturnal suppression of cocaine sensitization in C57BL mice could have been caused by the AANAT mutation/ deficiency and the inability of these mice to synthesize NAS and melatonin (Stehle et al, 2002; Uz and Manev, 2001; Uz et al, 2002a). Also Abarca et al (2002), who investigated the diurnal responsiveness of C57BL mice to cocaine sensitization, did not observe an absence of sensitization in these mice. These authors reported slight differences in the extent of cocaine-induced locomotor sensitization at different times during the day; the only procedure that abolished cocaine sensitization in these mice was mPer 1 knockout.

In conclusion, we demonstrated the existence of a strong correlation between the circadian pattern of mPER 1 cycling in the striatum and the diurnal development of cocaine sensitization, and we provide evidence that the pineal gland plays a critical role both in striatal mPer 1 rhythm and the development of diurnal cocaine sensitization. We postulate that these pineal gland-driven rhythms are mediated by pineal products such as NAS and/or melatonin, and that they might involve melatonin receptors expressed in the striatum. Further research is needed to confirm this putative role for NAS and melatonin in regulating striatal mPerl gene expression and rhythm, and in the development of circadian behavioral sensitization to cocaine. A more complete characterization of these mechanisms may help us better understand the mechanisms of drug abuse and identify novel targets for the prevention and/or treatment of addictions.

\section{ACKNOWLEDGEMENTS}

This research was supported by NIH Grants RO1 DA15072 (TU) and RO1 MH61572 (HM).

\section{REFERENCES}

Abarca C, Albrecht U, Spanagel R (2002). Cocaine sensitization and reward are under the influence of circadian genes and rhythm. Proc Natl Acad Sci USA 99: 9026-9030.

Andretic R, Chaney S, Hirsh J (1999). Requirement of circadian genes for cocaine sensitization in Drosophila. Science 285: $1066-1068$.

Dubocovich ML, Masana MI, Benloucif S (1999). Molecular pharmacology and function of melatonin receptor subtypes. Adv Exp Med Biol 460: 181-190. 
Etchegaray J-P, Lee C, Wade PA, Reppert SM (2003). Rhythmic histone acetylation underlies transcription in the mammalian circadian clock. Nature 421: 177-182.

Gaytan O, Lewis C, Swann A, Dafny N (1999). Diurnal differences in amphetamine sensitization. Eur J Pharmacol 374: 1-9.

Gaytan O, Yang P, Swann A, Dafny N (2000). Diurnal differences in sensitization to methylphenidate. Brain Res 864: 24-39.

Goto M, Oshima I, Tomita T, Ebihara S (1989). Melatonin content of the pineal gland in different mouse strains. J Pineal Res 7: 195-204.

Hasel KW, Sutcliffe JG (1990). Nucleotide sequence of a cDNA coding for mouse cyclophilin. Nucleic Acids Res 18: 4019.

Hirsh J (2001). Time flies like an arrow. Fruit flies like crack? Pharmacogenom J 1: 97-100.

Iijima M, Nikaido T, Akiyama M, Moriya T, Shibata S (2002). Methamphetamine-induced, suprachiasmatic nucleus-independent circadian rhythms of activity and mPer gene expression in the striatum of the mouse. Eur J Neurosci 16: 921-929.

Laakso A, Mohn AR, Gainetdinov RR, Caron MG (2002). Experimental genetic approaches to addiction. Neuron 36: 213-228.

Messager S, Garabette ML, Hastings MH, Hazlerigg DG (2001). Tissue-specific abolition of Per1 expression in the pars tuberalis by pinealectomy in the Syrian hamster. Neuroreport 12: 579-582.

Morse D, Sassone-Corsi P (2002). Time after time: inputs to and outputs from the mammalian circadian oscillators. Trends Neurosci 25: 632-637.

Paxinos G, Franklin KBJ (2001). The Mouse Brain in Stereotaxic Coordinates. Academic Press: London.

Prinssen EP, Kleven MS, Vignon J, Kamenka JM, Koek W (1996). Effects of repeated administration of $N$-[1-(2-benzo(b)-thiophenyl)cyclohexy]piperidine and cocaine on locomotor activity in C57BL/6 mice. J Pharmacol Exp Ther 276: 904-911.

Reppert SM, Godson C, Mahle CD, Weaver DR, Slaugenhaupt SA, Gusella JF (1995). Molecular characterization of a second melatonin receptor expressed in human retina and brain: the Mellb melatonin receptor. Proc Natl Acad Sci USA 92: 8734-8738.

Robinson TE, Berridge KC (1993). The neural basis of drug craving: an incentive-sensitization theory of addiction. Brain Res Brain Res Rev 18: 247-291.

Roca AL, Godson C, Weaver DR, Reppert SM (1996). Structure, characterization, and expression of the gene encoding the mouse Mella melatonin receptor. Endocrinology 137: 3469-3477.

Roseboom PH, Coon SL, Baler R, McCune SK, Weller JL, Klein DC (1996). Melatonin synthesis: analysis of the more than 150-fold nocturnal increase in serotonin $N$-acetyltransferase messenger ribonucleic acid in the rat pineal gland. Endocrinology 137: 3033-3045.

Sandyk R, Kanofsky JD (1992). Cocaine addiction: relationship to seasonal affective disorder. Int J Neurosci 64: 195-201.
Satel SL, Gawin FH (1989). Seasonal cocaine abuse. Am J Psychiatry 146: 534-535.

Sax KW, Strakowski SM (2001). Behavioral sensitization in humans. J Addict Dis 20: 55-65.

Sircar R (2000). Effect of melatonin on cocaine-induced behavioral sensitization. Brain Res 857: 295-299.

Stanewsky R (2003). Genetic analysis of the circadian system in Drosophila melanogaster and mammals. J Neurobiol 54: 111-147.

Stehle JH, von Gall C, Korf HW (2002). Organisation of the circadian system in melatonin-proficient $\mathrm{C} 3 \mathrm{H}$ and melatonindeficient C57BL mice: a comparative investigation. Cell Tissue Res 309: 173-182.

Sun ZS, Albrecht U, Zhuchenko O, Bailey J, Eichele G, Lee CC (1997). RIGUI, a putative mammalian ortholog of the Drosophila period gene. Cell 90: 1003-1011.

Terwilliger RZ, Beitner-Johnson D, Sevarino KA, Crain SM, Nestler EJ (1991). A general role for adaptations in G-proteins and the cyclic AMP system in mediating the chronic actions of morphine and cocaine on neuronal function. Brain Res 548: 100110.

Uz T, Manev H (1998). Circadian expression of pineal 5lipoxygenase mRNA. Neuroreport 9: 783-786.

Uz T, Manev H (2001). Prolonged swim-test immobility of serotonin $\mathrm{N}$-acetyltransferase (AANAT)-mutant mice. J Pineal Res 30: 166-170.

Uz T, Javaid JI, Manev H (2002a). Circadian differences in behavioral sensitization to cocaine: putative role of arylalkylamine $N$-acetyltransferase. Life Sci 70: 3069-3075.

Uz T, Qu T, Sugaya K, Manev H (2002b). Neuronal expression of arylalkylamine $\mathrm{N}$-acetyltransferase (AANAT) $\mathrm{mRNA}$ in the rat brain. Neurosci Res 42: 309-316.

von Gall C, Lewy A, Schomerus C, Vivien-Roels B, Pevet P, Korf HW et al (2000). Transcription factor dynamics and neuroendocrine signalling in the mouse pineal gland: a comparative analysis of melatonin-deficient $\mathrm{C} 57 \mathrm{BL}$ mice and melatoninproficient C3H mice. Eur J Neurosci 12: 964-972.

von Gall C, Schneider-Huther I, Pfeffer M, Dehghani F, Korf HW, Stehle JH (2001). Clock gene protein mPER1 is rhythmically synthesized and under cAMP control in the mouse pineal organ. J Neuroendocrinol 13: 313-316.

von Gall C, Garabette ML, Kell CA, Frenzel S, Dehghani F, Schumm-Draeger PM et al (2002). Rhythmic gene expression in pituitary depends on heterologous sensitization by the neurohormone melatonin. Nat Neurosci 5: 234-238.

Weaver DR, Liu C, Reppert SM (1996). Nature's knockout: the Mel1b receptor is not necessary for reproductive and circadian responses to melatonin in Siberian hamsters. Mol Endocrinol 10: $1478-1487$.

Wolf ME (1999). Cocaine addiction: clues from Drosophila on drugs. Curr Biol 9: R770-R772. 